\title{
ANALISIS POLA ASUH ORANG TUA DENGAN \\ KETERLAMBATAN BICARA PADA ANAK USIA 3-5 TAHUN
}

\author{
ANALYSIS OF PARENTING PATTERNS WITH SPEECH DELAY IN \\ CHILDREN AGED 3-5 YEARS
}

\author{
Miftakhur Rohmah ${ }^{1}$, Nita Dwi Astikasari, Iriyanti Weto \\ Prodi DIII Kebidanan STIKES Strada Kediri \\ 1Email : m1111ftaa@gmail.com
}

\begin{abstract}
ABSTRAK
Perkembangan anak merupakan bertambahnya kemampuan (skill) dalam struktur dan fungsi tubuh yang lebih kompleks dalam pola yang teratur dan dapat diramalkan, sebagai hasil dari proses pematangan, menyangkut adanya proses diferensiasi dari sel-sel tubuh, jaringan tubuh, organ-organ dan sistem organ yang berkembang sedemikian rupa sehingga masing-masing dapat memenuhi fungsinya . Salah satu aspek perkembangan yang memerlukan perhatian adalah perkembangan bahasa dan bicara. Gangguan bicara dan bahasa merupakan salah satu masalah yang sering terjadi pada anak-anak. Tujuan penelitian ini adalah menganalisis hubungan pola asuh orang tua dengan keterlambatan bicara pada anak usia 3-5 tahun. Desain penelitian ini adalah analitik observasional dengan pendekatan cross sectional. Populasi penelitian ini seluruh orang tua anak usia 3-5 tahun, dengan teknik Simple Random Sampling diperoleh sampel 32 responden. Analisa data menggunakan uji Chi Square. Hasil penelitian menunjukkan hampir setengah responden memiliki pola asuh dalam kategori permisif, yaitu 15 responden $(46,9 \%)$ dan sebagian besar responden memiliki keterlambatan bicara dalam kategori dicurigai terlambat bicara, yaitu 20 responden (62,5\%). Hasil analisa menggunakan uji Chi Square menunjukkan nilai $\mathrm{p}$-value $=0,025<\alpha=0,05$, sehingga $\mathrm{H}_{0}$ ditolak dan $\mathrm{H}_{1}$ diterima yang berarti ada hubungan pola asuh orang tua terhadap keterlambatan bicara pada anak usia 3-5 tahun.
\end{abstract}

Kata Kunci: Pola Asuh, Keterlambatan Bicara, Anak Usia 3-5 Tahun

\section{ABSTRACT}

Child development is an increasing skill for structure and function of the more complex body in an orderly and predictable pattern, as a result of the maturation process, involving the process of differentiation of the body's cells, tissues, organs and organ systems develop in such a way that each can fulfill its function. One aspect of development that needs attention is language development and speech. Speech and language disorders are one of the most common problems in children. Purpose of this study was to analize of parenting parents to speech delay in children aged 3-5 years. Design of this study was observational analytic with cross sectional approach. Population of this study all parents of children aged 3-5 years, with Simple Random Sampling technique obtained a sample of 32 respondents. Data analysis using Chi Square test. The results showed almost half of the respondents had a parenting pattern in the permissive category, which was 15 respondents (46.9\%) and most of the respondents had speech delay in the category of suspected late talk, ie 20 respondents (62.5\%). Result analysis using Chi Square test shows p-value $=0,025<\alpha=0,05$, so $H_{0}$ is rejected and $H_{1}$ accepted which means there was relation of parenting pattern to speech delay in children aged 3-5 years.

Keywords: Parenting, Speech Delay, Children Age 3-5 Years 


\section{LATAR BELAKANG}

Perkembangan merupakan adanya penambahan kemampuan (skill) berkaitan dengan struktur dan fungsi tubuh yang lebih kompleks dalam pola yang teratur serta dapat diramalkan, sebagai hasil dari proses pematangan, menyangkut adanya proses diferensiasi dari sel-sel tubuh, jaringan tubuh, organorgan dan sistem organ yang berkembang sehingga masing-masing dapat memenuhi fungsinya (Soetjiningsih, 2013). Salah satu aspek perkembangan yang memerlukan perhatian adalah perkembangan bahasa dan bicara.

Gangguan pada sektor bicara dan bahasa merupakan salah satu masalah yang paling sering terjadi pada anak terutama pada masa balita (Beyeng, 2012). Perkembangan bicara dan bahasa merupakan indikator seluruh perkembangan anak, karena perkembangan berbahasa sensitif terhadap keterlambatan atau kerusakan pada sistem lainnya sebab melibatkan perkembangan kognitif, sensori motorik, psikologis, emosi dan lingkungan sekitar (Soetjiningsih, 2013).

Berdasarkan National Center for Health Statistic (NCHS) orangtua melaporkan angka kejadian keterlambatan bicara pada anak adalah 0,9\% pada anak dibawah umur 5 tahun, dan $1,94 \%$ pada anak yang berumur 5-14 tahun. Berdasarkan hasil evaluasi secara langsung langsung, angka kejadian pada anak usia sekolah ternyata 3,8 kali lebih tinggi. Hal ini diperkirakan gangguan perkembangan pada sektor bicara dan bahasa pada anak adalah sekitar $4-5 \%$ (WHO, 2015).

Studi cochrane terakhir melaporkan bahwa pada anak usia prasekolah dan usia sekolah terdapat keterlambatan perkembangan bicara, bahasa dan gabungan keduanya. Prevalensi keterlambatan perkembangan bahasa dan bicara pada anak usia 2 sampai 4,5 tahun adalah 5-8\% (Ida, 2009).

Prevalensi keterlambatan perkembangan pada sektor berbahasa dan bicara di Indonesia belum pernah diteliti. Kendalanya adalah dalam menentukan kriteria keterlambatan perkembangan berbahasa, namun berdasarkan survei epidemiologik di 7 provinsi pada tahun 2014 diperkirakan prevalensi keterlambatan bicara pada anak di Indonesia sekitar 3-10\% dari jumlah seluruh balita yang ada (Komnas Penanggulangan Gangguan Pendengaran \& Ketulian, 2016). 
Ikatan Dokter Anak Indonesia (IDAI) Jawa Timur pada tahun 2014 melakukan pemeriksaan terhadap 2.634 anak dari usia 0-72 bulan. Dari hasil pemeriksaan untuk sektor perkembangan bahasa ditemukan adanya penyimpangan perkembangan bahasa pada 394 anak (15,0\%) (IDAI Jatim, 2014). Sedangkan data dari Dinas Kesehatan Kota Kediri bulan Januari-Maret 2016 ada 9.519 balita terdiri dari 4.710 balita laki-laki dan 4.809 balita perempuan yang sudah dilakukan skrining atau deteksi dini penyimpangan tumbuh kembang balita di Puskesmas didapatkan prevalensi keterlambatan bicara pada anak usia balita sebesar $12,3 \%$.

Hasil studi pendahuluan yang dilakukan di TK PB An Nur Kelurahan Tosaren Kota Kediri didapatkan siswa yang diidentifikasi mengalami keterlambatan bicara sebanyak 10 anak. Dari 10 anak tersebut, 5 anak telah dilakukan wawancara informal kepada orang tuanya dan diketahui 4 orang tua suka bersikap memerintah anak untuk melakukan sesuatu tanpa kompromi sehingga komunikasi diantara keduanya kurang terjalin. Sedangkan 1 orang tua lainnya cenderung menyatakan pendapat atau pertanyaan serta memberikan penjelasan tentang dampak perbuatan yang baik dan yang buruk sehingga frekuensi komunikasi keduanya terlihat lebih intensif (Hasil Studi Pendahuluan, 2017). Bicara adalah suatu kumpulan dan keterampilan mental dan motorik, bicara dan bahasa juga merupakan suatu kemampuan mengkaitkan arti dan bunyi yang di dapatkan atau dikeluarkan (Soetjiningsih, 2013).

Menurut Dhinie (dalam Restiyani, 2013) keterlambatan pada bidang-bidang pertumbuhan dan perkembangan anak disebabkan oleh kurangnya perhatian, bimbingan dan pengetahuan orang tua terhadap perkembangan psikologi dan psikososial anak dalam setiap jenjang usianya.

Kondisi ini disebabkan oleh penerapan pola asuh yang tidak sesuai dengan karakter anak. Menurut kartono (2008), pola asuh anak yang tidak disesuaikan dengan kebutuhan anak tidak dapat memberikan outcome yang positif. Setiap tahapan perkembangan anak membutuhkan pola asuh yang berbeda, tanpa memperhatikan kapan menerapkan sikap otoriter, demokratis, ataupun faire, tidak dapat menyebabkan anak terdukung perkembangannya dari seluruh aspek. Pola asuh yang tidak tepat, misalnya dengan membiarkan anak berlama-lama bermain dengan 
mainannya menyebabkan anak kurang dapat mengembangkan kemampuan motorik halusnya, selain itu juga menyebabkan anak kurang terasah kemampuan sosialisasinya yang pada akhirnya terjadi keterlambatan bicara.

Menurut Hurlock (2006) dikatakan bahwa pola asuh orang tua terbagi menjadi 3 tipe pola asuh orang tua yaitu: pola asuh ortoriter, adalah pola asuh yang mengarah kedisiplinan, orang tua menetapkan peraturan-peraturan yang harus dipatuhi oleh anaknya. Pola asuh Persimif adalah orang tua dengan pola asuh yang lebih memanjakan anaknya, pola asuh ini akan berakibat anak akan lebih agresif dan tidak patuh terhadap orang tuanya.

Pola asuh demokrasi adalah yang memberikan dan memperhatikan kebutuhan anaknya, dengan demikian prinsip ini menekan hak anak untuk mengetahui mengapa peraturanperaturan dibuat dan memperoleh kesepatan untuk mengemukakan pendapatnya sendiri bila ingin memprotes aturan itu tidak adil.

Orang tua hendaknya memperhatikan setiap kebutuhan untuk perkembangan anaknya, diantaranya: makanan, kesehatan, kasih sayang, nutrisi dan stimulasi, rasa aman yang konsisten, serta permainan yang memungkinkan anak untuk berimajinasi. Salah satu upaya yang dapat dilakukan untuk mencegah terjadinya keterlambatan bicara pada anak dengan cara rajin berbicara dan berkomunikasi dengan anak serta membacakan cerita adalah cara yang baik untuk meningkatkan kosakata anak. Bayi dan anak kecil biasanya tertarik pada cerita yang bersajak. Sembari membaca, anak dapat diajak menunjuk gambar dan menyebut nama benda yang ditunjuk.

Keterlambatan perkembangan bicara dan bahasa sebaiknya dapat dikenali oleh orangtua sedini mungkin, agar tatalaksana yang diberikan dapat memaksimalkan kapasitas bicara dan bahasa yang dimiliki anak-anak. Tujuan penelitan ini yaitu menganalisa hubungan pola asuh orang tua dengan keterlambatan bicara pada anak usia 3-5 tahun.

\section{METODE PENELITIAN}

Desain penelitian yang digunakan adalah cross sectional, populasi dalam penelitian ini adalah semua orang tua yang memiliki anak usia 3-5 tahun yang berjumlah 35 anak, dan pengambilan sampel menggunakan teknik simple random sampling diperoleh sampel 
berjumlah 32 responden. Cara pengambilan sampel yaitu dengan menggunkaan tabel bilangan random. Variabel Independen dalam penelitian ini adalah Pola Asuh Orang Tua, sedangkan variabel dependen dalam penelitian ini adalah Keterlambatan bicara. Instrumen penelitian yang digunakan yakni kuesioner untuk pola asuh orangtua dan lembar observasi untuk keterlambatan bicara (speech delay). analisis data yang digunakan adalah uji Chi Square.

\section{HASIL DAN PEMBAHASAN}

Berdasarkan hasil uji statistik didapatkan hasil sebagaimana tabel 1:

Tabel 1. Pola asuh orang tua pada anak usia

\begin{tabular}{|c|c|c|c|}
\hline No & Pola Asuh & Frekuensi & $\%$ \\
\hline 1 & Otoriter & 6 & 18,8 \\
\hline 2 & Permisif & 15 & 46,9 \\
\hline \multirow[t]{2}{*}{3} & Demokratis & 11 & 34,4 \\
\hline & Jumlah & 32 & 100,0 \\
\hline
\end{tabular}

Berdasarkan tabel 1 diketahui bahwa hampir setengah responden memiliki pola asuh dalam kategori permisif, yaitu 15 responden $(46,9 \%)$.

Tabel 2.Keterlambatan bicara (Speech delay) pada anak usia 3-5 tahun

\begin{tabular}{|c|c|c|c|}
\hline \multicolumn{3}{|c|}{ Keterlambatan } & \multirow[b]{2}{*}{$\%$} \\
\hline No & Bicara & Frekuensi & \\
\hline \multirow{3}{*}{1} & Dicurigai & & \\
\hline & Terlambat Bicara & 20 & 62,5 \\
\hline & Tidak Terlambat & & \\
\hline \multirow[t]{2}{*}{2} & Bicara & 12 & 37,5 \\
\hline & Jumlah & 32 & 100,0 \\
\hline
\end{tabular}

Berdasarkan tabel 2 diketahui bahwa sebagian besar responden memiliki keterlambatan bicara dalam kategori dicurigai terlambat bicara, yaitu 20 responden $(62,5 \%)$.

Tabel 3. Hubungan pola asuh orang tua dengan keterlambatan bicara pada anak usia 3-5 tahun

\begin{tabular}{|c|c|c|c|c|c|}
\hline & \multicolumn{4}{|c|}{ Keterlambatan Bicara } \\
\hline & & & $\begin{array}{c}\text { Dicurigai } \\
\text { Terlambat Bicara }\end{array}$ & $\begin{array}{c}\text { Tidak Terlambat } \\
\text { Bicara }\end{array}$ & Total \\
\hline \multirow{6}{*}{ Pola Asuh } & \multirow[b]{2}{*}{ Otoriter } & Count & 3 & 3 & 6 \\
\hline & & $\%$ of Total & $9,4 \%$ & $9,4 \%$ & $18,8 \%$ \\
\hline & \multirow{2}{*}{ Permisif } & Count & 13 & 2 & 15 \\
\hline & & $\%$ of Total & $40,6 \%$ & $6,3 \%$ & $46,9 \%$ \\
\hline & \multirow{2}{*}{ Demokratis } & Count & 4 & 7 & 11 \\
\hline & & $\%$ of Total & $12,5 \%$ & $21,9 \%$ & $34,4 \%$ \\
\hline \multirow{3}{*}{\multicolumn{2}{|c|}{ Total }} & Count & 20 & 12 & 32 \\
\hline & & $\%$ of Total & $62,5 \%$ & $37,5 \%$ & $100,0 \%$ \\
\hline & & $p-1$ & $=0,025$ & & \\
\hline
\end{tabular}


Tabulasi silang menunjukkan bahwa responden memiliki pola asuh permisif dengan keterlambatan bicara dalam kategori dicurigai terlambat bicara, yaitu 13 responden $(40,6 \%)$. Hasil analisis menggunakan Chi square dapat menunjukkan nilai $p=0,025<a$ $=0,05$, maka Ho ditolak dan H1 diterima yang berarti ada hubungan pola pengasuhan orang tua terhadap keterlambatan bicara (Speech delayed) pada anak usia 3-5 tahun.

Pola asuh orang tua pada anak usia 3-5 tahun diketahui bahwa hampir setengah responden memiliki pola asuh dalam kategori permisif, yaitu 15 responden $(46,9 \%)$.

Pola asuh adalah cara atau proses mendidik agar kepribadian anak dapat berkembang dengan baik, ketika dewasa menjadi tanggung jawab. Perkembangan diri anak sangat dipengaruhi pola asuh yang diterapkan oleh orangtua (Yusuf, 2008).

Menurut Kartono (2005), pola asuh anak yang tidak disesuaikan dengan kebutuhan anak tidak dapat memberikan outcome yang positif dan sering kali hanya membuang waktu. Setiap tahapan perkembangan anak membutuhkan pola asuh yang berbeda, prinsip orang tua sebagai contoh, orang tua sebagai pembimbing dan orang tua sebagai pengawas harus selalu diperhatikan.

Tanpa memperhatikan kapan menerapkan sikap otoriter, demokratis, ataupun faire, tidak dapat menyebabkan anak terdukung perkembangannya dari seluruh aspek. Menurut Papalia (2013) pola asuh demokratis dipandang lebih kondusif dalam mendidik karakter anak, sedangkan pola asuh otoriter dimana orang tua berusaha membuat anak mematuhi standar perilaku yang telah ditetapkan oleh orang tua danmemberikan hukuman secara tegas apabila anak melanggarnya.

Hasil penelitian menunjukkan bahwa sebagian besar responden dalam menerapkan pola asuh dalam kategori permisif. Hal ini dapat disebabkan karena orang tua anak kurang dapat memahami cara pemenuhan kebutuhan anak dalam arti pola asuh dengan tepat.

Kebanyakan orang tua dalam memperlakukan anak didasari oleh rasa belas kasihan sehingga muncul kecenderungan orang tua dalam melaksanakan pola asah cenderung permisif, yaitu membiarkan anak bertindak sesuka hatinya tanpa ada arahan dari orang tua karena orang tua kasihan dengan anaknya. Hal ini berdampak pada terjadinya 
permasalahan pada anak dimana anak semakin sulit dikendalikan dan perkembangannya tidak terlatih dengan baik.

Pola asuh yang dinilai memiliki pengaruh baik terhadap perkembangn anak adalah pola asuh demokratis, dimana sikap orang tua dalam memberikan pengasuhan pada anak dengan cara memberikan kesempatan pada anak untuk membuat pilihan yang disukainya.

Orang tua dengan pola asuh demokratis percaya akan kemampuan mereka dalam memandu anak, tetapi juga menghargai keputusan mandiri, minat, pendapat, dan kepribadian anak. Interaksi dan respon yang diberikan oleh orang tua berperan penting dalam perkembangan bahasa anak. Pola asuh demokratis mampu membuat anak-anak lebih mudah mencapai kemampuan berbahasa karena anak menerima contoh berbahasa, berekspresi dan berperilaku yang baik dari keluarga sehingga komunikasi serta interaksi yang terjalin akan meningkatkan perbendaharaan kata, keberanian dan keterampilan berkomunikasi dengan baik.

Keterlambatan bicara (Speech delay) pada anak usia 3-5 tahun diketahui bahwa sebagian besar responden memiliki keterlambatan bicara dalam kategori dicurigai terlambat bicara, yaitu 20 responden $(62,5 \%)$.

Perkembangan bicara dan bahasa merupakan indikator seluruh perkembangan anak, karena perkembangan berbahasa sensitif terhadap keterlambatan atau kerusakan pada sistem lainnya sebab melibatkan perkembangan kognitif, sensori motorik, psikologis, emosi dan lingkungan di sekitar anak (Soetjiningsih, 2013).

Menurut Hurlock (2010), dikatakan terlambat bicara apabila tingkat perkembangan bicara berada di bawah tingkat kualitas perkembangan bicara anak yang umurnya sama yang dapat diketahui dari ketepatan penggunaan kata. Apabila pada saat teman sebaya mereka berbicara dengan menggunakan kata-kata, sedangkan anak terus menggunakan isyarat dan gaya bicara bayi maka anak yang demikian dianggap orang lain terlalu muda untuk diajak bermain.

Hasil penelitian menunjukkan bahwa sebagian besar responden dicurigai mengalami keterlambatan bicara. Kecerdasan dapat menjadi salah satu faktor anak mengalami keterlambatan dalam berbicara dikarenakan umumnya subjek penelitian 
memiliki kecenderungan menyendiri dan kurang melibatkan diri dalam suatu percakapan. Anak yang memiliki IQ tinggi biasanya lebih mudah, lebih tertarik, dan lebih lancar berbicara ketimbang anak yang kurang cerdas, karena kemampuan mereka berbicara, orang dewasa dan teman sebaya mendorong mereka berbicara lebih banyak, ketimbang teman sebaya mereka yang kurang cerdas yang biasanya kurang berminat ikut serta dalam percakapan.

Penggunaan bahasa kedua (Second Langunge) juga dapat menjadi penyebab anak mengalami keterlambatan dalam berbicara. Bahasa kedua yang dimaksud ialah penggunaan bahasa Indonesia dan bahasa Jawa. Penggunaan bahasa kedua yang menyebabkan anak bingung serta salah dalam mengekspresikan perasaan mereka terhadap teman sebaya maupun orang dewasa yang ada disekitarnya sehingga menjadikan mereka menarik diri dari lingkungan sosialnya. Selanjutnya gaya bicara/model yang ditiru menjadi salah satu faktor anak terlambat dalam berbicara dikarenakan sikap atau perlakuan yang ditunjukkan oleh orang dewasa di sekitar anak kurang baik atau tidak sesuai.
Gaya bicara atau model yang ditiru subjek saat berada di sekolah tidak sejalan dengan di rumah, dikarenakan pola pengasuhan yang diterapkan di rumah cenderung mengikuti kemauan anak serta penggunaan bahasa yang tidak konsisten yang menyebabkan anak terlambat dalam berbicara. hubungan keluarga dan faktor kesehatan.

Tabulasi silang menunjukkan bahwa responden memiliki pola asuh permisif dengan keterlambatan bicara dalam kategori dicurigai terlambat bicara, yaitu 13 responden $(40,6 \%)$. Hasil analisis Chi square dapat menunjukkan nilai $\mathrm{p}=0,025<\alpha=0,05$, maka Ho ditolak dan H1 diterima yang berarti ada hubungan pola asuh orang tua dengan keterlambatan bicara pada anak usia 3-5 tahun.

Orang tua hendaknya memperhatikan setiap kebutuhan untuk perkembangan anaknya, diantaranya: makanan, kesehatan, kasih sayang, nutrisi dan stimulasi, rasa aman yang konsisten, serta permainan yang memungkinkan anak untuk berimajinasi. Perhatian, bimbingan dan pengetahuan orang tua terhadap perkembangan psikologi dan psikososial anak dalam jenjang usianya mampu mempengaruhi 
tingkat kemampuan anak

(Moersintowarti dkk, 2012).

Pemberian stimulasi melalui pola asuh yang tepat oleh keluarga sangat penting bagi perkembangan balita, mengingat keluarga merupakan lingkungan sosial terdekat dari balita sehingga sering berinteraksi dengan balita. Semakin baik stimulasi yang diberikan oleh keluarga maka semakin baik pula perkembangan balita. Untuk itu diperlukan upaya pemberian informasi dan motivasi kepada keluarga agar dapat menberikan stimulasi secara optimal (Kartono, 2008).

Soetjiningsih (2005) yang menyatakan bahwa perkembangan bicara dan bahasa merupakan indikator seluruh perkembangan anak, karena perkembangan berbahasa sensitif terhadap keterlambatan atau kerusakan pada sistem lainnya sebab melibatkan perkembangan kognitif, sensori motorik, psikologis, emosi dan lingkungan di sekitar anak.

Berdasarkan data penelitian menunjukkan bahwa pola asuh yang paling banyak dimiliki orang tua adalah pola asuh permisif dimana orang tua dengan pola asuh ini bersikap acceptance tinggi namun kontrolnya rendah, memberi kebebasan kepada anak untuk menyatakan dorongan atau keinginan Selain itu hasil penelitian juga disimpulkan bahwa terdapat hubungan yang signifikan antara pola asuh dengan keterlambatyan bicara pada anak. Orang tua dan lingkungan terdekat memegang peranan penting dalam perkembangan bicara dan bahasa seorang anak. Kosakata anak berbanding lurus dengan jumlah kata yang didengarnya pada masa kritikal perkembangan bicaranya.

Hal-hal yang dapat dilakukan orang tua untuk mengoptimalkan perkembangan bicara dan bahasa anak antara lain rajin berbicara dan berkomunikasi dengan anak dan membacakan cerita adalah cara yang baik untuk meningkatkan kosakata anak. Bayi dan anak kecil biasanya tertarik pada cerita yang bersajak. Sembari membaca, anak dapat diajak menunjuk gambar dan menyebut nama benda yang ditunjuk.

Keterlambatan perkembangan bicara dan bahasa sebaiknya dapat dikenali oleh orang tua sedini mungkin, agar tatalaksana yang diberikan dapat memaksimalkan kapasitas bicara dan bahasa yang dimiliki anak. 


\section{SIMPULAN DAN SARAN}

Simpulan dari hasil penelitian menununjukkan bahwa terdapat hubungan pola asuh orang tua terhadap keterlambatan bicara pada anak usia 3-5 tahun $(p=0,025<\alpha=0,05)$, dan diharapkan kepada setiap orang tua dapat meningkatkan perkembangan bahasa anak sehingga tidak terjadi keterlambatan bicara motorik halus anak dengan menerapkan pola asuh yang lebih baik yaitu demokratis kepada anak.

\section{DAFTAR PUSTAKA}

Adriana, 2013. Tumbuh Kembang \& Terapi Bermain Pada Anak. Jakarta: Selemba Medika

Andriani, Merryana., Maria, F.N., 2011. Hubungan Pola Asuh, Asih, Asah dengan Tumbuh Kembang Balita Usia 1-3 Tahun. The Indonesian Journal of Public Health. Vol. 6. No. 1. April 2017

Arikunto, 2008. Prosedur Penelitian Suatu Pendekatan Praktek. Jakarta: Rineka Cipta

Asmadi, 2010. Konsep Dasar Keperawatan, Jakarta : EGC

Astuti, 2007. Pengantar Ilmu Statistik untuk Peternakan dan Kesehatan Hewan. Cetakan pertama. Binasti Publisher, Bogor
Baumrind, 2008. Pola asuh otoritas orang tua. Jakarta:Yayasan Obor Indonesia

Chaer, 2009. Pengantar Semantik Bahasa Indonesia. Jakarta: Rineka Cipta

Hidayat, 2012. Pengantar Kebutuhan Dasar Manusia: Aplikasi Konsep dan proses Keperawatan. Jakarta: salemba Medika

Hidayat, A.A.A, 2008. Metode Penelitian Kebidanan Teknik Analisa Data. Jakarta: Salemba Medika

Hidayat, A.A.A. 2010, Riset keperawatan dan teknik penulisan ilmiah. Jakarta: Salemba Medika

Hoetomo, 2010. Kamus Lengkap Bahasa Indonesia. Jakarta: Mitra Pelajar

Hurlock, 2010. Psikologi Perkembangan : Suatu Pendekatan Sepanjang Rentang Kehidupan. Edisi Kelima (Alih Bahasa : Istiwidayanti dan Soedjarwo) Jakarta: Erlangga

IDAI, 2013, Keterlambatan Bicara. Artikel tahun 2013: http://www.idai.or.id/artikel/kl inik/keluhananak/keterlambatan-bicara. [Diakses tanggal 5 Juni 2017]

Judarwanto. 2010. Deteksi Dan Kenali Keterlambatan Bicara Pada Anak Sejak Dini. https://klinikanakonline.com/2 010/11/03/deteksi-dan-kenaliketerlambatan-bicara-pada- 
anak-sejak-dini/ [Diakses
tanggal 14 Juni 2017]

Notoatmodjo, 2010. Pendidikan Dan

Perilaku Kesehatan. Rineka Cipta. Jakarta

Notoatmodjo, S. 2010. Metodologi Penelitian Kesehatan. Jakarta: Rineka Cipta

Nursalam, S. 2010. Asuhan Keperawatan Bayi dan Anak. Jakarta : Salemba Medika

Nursalam, 2008. Konsep Dan Penerapan Metodologi Penelitian Ilmu keperawatan. Edisi 2. Jakarta : Salemba Medika
Soemiarti Patmonodewo. 2003. Pendidikan Anak Pra Sekolah. Jakarta:Rineka Cipta

Soetjiningsih. 2013. Tumbuh Kembang Anak. Jakarta: EGC

Sugiyono, 2010. Metode Penelitian Kuantitatif Kualitatif \& RND. Bandung : Alfabeta

Supartini, Yupi, 2004, Buku Ajar Konsep Dasar Keperawatan Anak. Jakarta: EGC

Wong and Whaley's, 2008, Psikologi Perkembangan Anak Dan Remaja, Remaja Rosda Karya. Bandung Edisi 1. Jakarta: Salemba Medika 